Volume 5 Number 1, January-June 2021: pg. 23-38.

Fakultas Hukum, Universitas Lampung,

Bandar Lampung, Lampung, Indonesia.

E-ISSN: 2598-3105 P-ISSN: 2723-2581

http://jurnal.fh.unila.ac.id/index.php/cepalo

\title{
POLICY ON OVERCOMING VILLAGE BUDGET DEVIATIONS BY THE GOVERNMENT INTERNAL SUPERVISORY APPARATUS IN INDONESIA (CASE STUDY OF TANJUNGSARI VILLAGE, LAMPUNG)
}

\author{
I Ketut Seregig ${ }^{1}$, Bambang Hartono ${ }^{2}$, Yustina Ndari ${ }^{3}$ \\ ${ }^{1}$ Faculty of Law, Universitas Bandar Lampung, Email: iketutseregig@ubl.ac.id \\ ${ }^{2}$ Faculty of Law, Universitas Bandar Lampung Email: bambang.hartono@ubl.ac.id \\ ${ }^{3}$ Universitas Bandar Lampung, Email: yustinandari228@gmail.com
}

Submitted: January 6, 2021; Reviewed: February 11, 2021; Accepted: March 3, 2021

DOI: 10.25041/cepalo.v5no1.2211

\begin{abstract}
Corruption is deeply rooted in Indonesia. This fact is undeniable when this crime has occurred at the lowest government level, namely in the village government. One sample of cases raised in this study is the alleged Corruption Crime committed by the Head of Tanjungsari Natar Village, South Lampung, named Robangi. The problems examined in this alleged criminal act are the factors causing the perpetrator to commit the criminal act of corruption. Second, the pattern of countermeasures carried out by APIP in resolving the case. The method used is qualitative and in the research data collection using a normative juridical approach and empirical juridical. Meanwhile, the theory used as a knife of analysis is the theory of Non-Penal Policy proposed by Muladi and Barda Nawawi Arief, which states that "non-penal policy is the prevention of crime which prioritizes the prevention of crimes committed by guidance, aims to prevent before the crime occurs, and/or the perpetrator does not repeat his actions".The results showed that the factors causing the perpetrator to commit these acts were because the project implementation was not following the proposal, the use of funds was not per the project proposal (total loss), the reason was that at the request of the community, the planned construction was moved to another place. This act is procedurally violating the SOP for the management of state finances. However, empirical facts prove no state loss in the corruption crime allegedly committed by the village head. Based on these facts, APIP South Lampung Regency has implemented a countermeasures policy by imposing administrative sanctions on the village head of Tanjungsari, Natar District, South Lampung.
\end{abstract}

Keywords: Corruption, State Losses, Policy.

\section{A. Introduction}

Corruption carried out empirically by state officials has taken root to the lowest level of officials, ${ }^{1}$ namely the Village Head or Village Chief. In general, the factors causing corruption

\footnotetext{
${ }^{1}$ Marten Bunga, Aan Aswari, Hardianto Djanggih, "KONSEPSI PENYELAMATAN DANA DESA DARI PERBUATAN KORUPSI", Halu Oleo Law Review 2, no. 2 (2018):448-459, 451, DOI: 10.33561/holrev.v2i2.4318.
} 
committed by village heads in Indonesia are due to legal factors, personal factors and society factors. ${ }^{2}$ Another factor is the lack of ability of village heads in the management of state finances so that many cases of corruption committed by village heads. The development project sector is often one of the areas for corruption both in the central levels and in village levels. ${ }^{3}$ Incomplete village project administration and village project planning that is incompatible with the activities carried out even though the volume of project activities generated exceeds the project planning submitted to the country. The facts found in the field based on community complaints are as follows; the location of the project moved, activities changed from the plan, and the funds that were rolled out to the Village by the government were considered to belong to the village head so that they could be used for village progress without being guided by the proposed project plan.

To give an overview of corruption that occurred at the village level, in this study, we will analyze one case of corruption committed by the Head of Tanjungsari Village, Natar District, South Lampung. A sampling of this case was carried out using a purposive sampling method, one of the Village Head's corruption cases in the South Lampung region - Indonesia. This case is considered to have represented a criminal act of corruption committed by the village head in South Lampung Regency. This is a sample of one model of corruption carried out in Indonesia. Considering a large number of complaints of village head corruption cases reported by the community to the Government Internal Oversight Apparatus (from now on abbreviated to APIP), this case sample can also be used as an illustration in responding to reports from the community about corruption committed by the village head so that the community members understand juridically elements of corruption that occur in the use of village budgets.

In tackling corruption at the village level, it is necessary to build good coordination between APIP and APH (Law Enforcement Officers). This is intended so that public complaints about corruption can be carried out constructively and integrated between APIP and APH. The problem that will be examined in this study is how the village fund management is carried out by the village head and coordination between APIP and APH in handling deviations from the Village Budget, especially those carried out in Tanjung Sari Village, Natar District, South Lampung Regency.

The approach used in this study is a normative and empirical juridical approach through structured interview activities by conducting calls and examining the suspected village head (Robangi), the Village Development Head, and several community members. They are located around the village project and other community members. They are related to complex village projects. After calling and asking for information, the APIP Team conducted an empirical study of village projects targeted as investigations in Tanjungsari Natar, which allegedly occurred irregularities and indicated corruption. Based on the information and facts found in the field, we then analyzed qualitatively to find the causes of corruption in village funds reported by the community.

\section{Government Policy Issues}

In order to realize the achievement of the 'NawaCita' Program launched by President Jokowi /JK during the 2014-2019 administration ${ }^{4}$, by paying attention and evaluating the implementation of strategic programs than in accelerating the implementation of national projects in the regions and overcoming obstacles and community reports related to the

\footnotetext{
${ }^{2}$ Dian Herdiana, "KECENDERUNGAN PERILAKU KORUPTIF KEPALA DESA DALAM PEMBANGUNAN DESA", Matra Pembaruan 3, no. 1 (2019): 1-11, DOI: 10.21787/mp.3.1.2019.1-11.

${ }^{3}$ Shela Delvia Hans, et.al, "PENGELOLAAN DANA DESA DI TINJAU DARI PERSPEKTIF PENCEGAHAN KORUPSI", Jurnal Akta Yudisia 5, no. 1 (2020): 1-26, 8, DOI: 10.35334/ay.v5i1.1215.

4 https://nasional.kompas.com/read/2014/05/21/0754454/.Nawa.Cita.9.Agenda.Prioritas.Jokowi-JK, accessed March 6, 2020).
} 
implementation of national strategic projects in the regions, on January 8, 2016, the President of the Republic of Indonesia issued Instructions of the President of the Republic of Indonesia Number 1 of 2016 concerning the Acceleration of the Implementation of National Strategic Projects addressed to the Cabinet Ministers Employment, Attorney General of the Republic of Indonesia, Head of the Indonesian National Police; Secretary of State; Presidential Chiefs of Staff, Heads of Non-Ministry Government Institutions, Governors, and Regents/Mayors. The contents of the Presidential Instruction amounted to 11 points. In the first point, the President of the Republic of Indonesia instructed them to do the following things:

Take the necessary steps according to their respective duties, functions, and authorities to accelerate the implementation of the National Strategic Project and/or provide support in accelerating the implementation of the National Strategic Project, which includes (1) Project preparation (2) Project land acquisition (3) Project funding (4) Licensing and nonlicensing (5) Implementation of physical development (6) Supervision and control (7) Provision of legal considerations; and/or (8) Legal and non-legal risk mitigation.

Along with the issuance of Presidential Instruction of the Republic of Indonesia Number 1 of 2016 concerning the Acceleration of the Implementation of National Strategic Projects, the government has also issued Government Regulation Number 12 of 2017 concerning Development and Supervision of Regional Government Operations, in the General Provisions in Chapter I Article 1 point 3 stated "Supervisory Apparatus Internal Government, hereinafter referred to as APIP, is the inspectorate general of the ministry, the oversight unit of the nonministerial government agency, the provincial inspectorate and the district/city inspectorate.

This is related to the scope of duties and authority regulated in article 3 paragraph (2), it is stated that "general guidance as referred to in paragraph (1) letters 'a' and 'b' includes: a. Division of government affairs b. Regional Institution c. Staffing in regional apparatus d. Regional finance, e. Regional Development f. Public services in the area g. Regional cooperation $\mathrm{h}$. Regional policy i. Regional Head and DPRD and j. Other forms of coaching that comply with statutory provisions.

While article 3 paragraph (3) states 'technical guidance' as referred to in paragraph (1) letter 'a' number 2 is carried out on the technical implementation of government affairs submitted to the provincial area and technical guidance as referred to in paragraph (1) letter 'b' carried out on the technical implementation of government affairs submitted to the district/city. The implementation of general supervision and technical supervision at the regional government is regulated in Article 10 paragraph (2), paragraph (3), and paragraph (4) as follows:

\section{Article 10 Paragraph (2)}

General supervision as referred to in paragraph (1) letter 'a' number 1 and letter 'b' includes: a. Division of government affairs, b. Regional Institution, c. Staffing in regional apparatus, d. Regional finance, e. Regional Development, f. Public services in the area, g. Regional Cooperation, h. Regional policy, i. Regional Head and Regional People's Representative Council, j. Other forms of coaching that comply with statutory provisions.

\section{Article 10 paragraph (3)}

Technical supervision as referred to in paragraph (1) letter 'a' number 2 is carried out on the technical implementation of government affairs submitted to the provincial area, and technical guidance as referred to in paragraph (1) letter ' $b$ ' is carried out on the technical implementation of government affairs submitted to the regions district/city level.

\section{Article 10 paragraph (4)}


Technical supervision as referred to in paragraph (3) includes (a) achievement of minimum service standards for essential services, (b) compliance with statutory provisions including compliance with norms, standards, procedures, and criteria set by local governments, and (c) accountability in the management of the state revenue and expenditure budget in the implementation of concurrent governmental affairs in the regions.

In carrying out the development and supervision of the concurrent regional government, APIP is a unit in the regional government inspectorate whose duty is to ensure a clean and accountable government as described in Article 3 and Article 10 above. This includes fostering and overseeing state revenue and expenditure budgets in the regions, both provincial and district/city.

In connection with the fostering and supervision of regional budgets and expenditure (hereinafter referred to as APBD) in South Lampung Regency, the APIP at the South Lampung Inspectorate has received many complaints community regarding the deviation of village funds by the village head. Reported deviations are generally labor-intensive project activities that do not follow the proposed plan or have changed from previous planning. There are also reports on financial management that are not transparent so that the village head is considered to have cheated in managing village funds. Based on these reports, APIP conducted an investigation, checked into the field, and summoned parties related to the community report. This activity was carried out in coordination with other APIP members, namely the Financial and Development Supervisory Agency, starting now abbreviated as BPKP and Law Enforcement Officials, after this abbreviated as APH Police Investigators and Prosecutors' Investigators.

Referring to the government regulation mentioned above, if in the investigation, APIP finds indications of criminal acts of corruption committed by the village head, then the policy in its response is that within 60 days, the state losses calculated by BPKP must be returned to the state. If the village head does not return the loss to the country during this period, APIP will forward the results of its investigation to APH for investigation.

The authority as stipulated in the government policy according to the definition of government stated by Hadjon can be understood through 2 meanings, namely (1) seen from the function of government or government activities and (2) viewed from the aspects of the organization of government or a collection of government entities. However, the government's overall function consists of various kinds of government actions, among others in decisions or decrees that are general, civil legal actions, and concrete actions. Only legislation derived from political and judicial authority by judges is omitted. ${ }^{5}$ Montesquieu mentioned that in the state government there are 3 (three) types of government power, namely the legislative, executive and judicial power. ${ }^{6}$ According to Jimly Asshidiqie, the government system is defined as a system of relations between state institutions. ${ }^{7}$ Meanwhile, the governance system in Indonesia is based on the principles of good governance. ${ }^{8}$

In Suhady's view, the term government is "the authoritative direction and administration of

\footnotetext{
${ }^{5}$ Philipus M Hadjon, Pengantar Hukum Administrasi Indonesia (Yogyakarta: Gajah Mada University Press, 1993), 6-8.

6 Ahmad Yani, "SISTEM PEMERINTAHAN INDONESIA: PENDEKATAN TEORI DAN PRAKTEK KONSTITUSI UNDANG-UNDANG DASAR 1945 (Indonesian Government System: Theory and Practice Approaches of $1945^{\prime}$ Constitution)", Jurnal Kebijakan Hukum 12, no. 2 (2018): 119-135, 125, DOI: 10.30641/kebijakan.2018.V12.119-135.

${ }^{7}$ Cora Elly Noviati, "DEMOKRASI DAN SISTEM PEMERINTAHAN", Jurnal Konstitusi 10, no. 2 (2013): 333354, 337, DOI: $10.31078 / \mathrm{jk} \% 25 \mathrm{x}$.

8 Novie Indrawati Sagita, "PARTISIPASI WARGA MASYARAKAT DALAM PENILAIANKINERJA KECAMATAN DI KOTA BANDUNG", CosmoGov 2, no. 2 (2016): 308-329, 309, DOI: 10.24198/cosmogov.v2i2.10009.
} 
men/women's affairs in a nation-state, city, etc."9 This means that the government functions as a director and administrator in charge of community activities in a country, city, and so on. The government can also be interpreted as "the governing body of a nation, state, city, etc." This means that the government is an institution or body that organizes the government of a country, state, or city, and so on. ${ }^{10}$

\section{Definition of Village}

The term Village in Indonesia varies according to each region's local wisdom, both between regencies/cities in the Province and between Provinces throughout Indonesia. Especially in Lampung Province, the term village is variously called. Some say 'Pekon', 'Kampung', 'Desa'. All of them contain the same definition, which is the same as the village definition in general. Law No. 6 of 2014 concerning Villages in Chapter I concerning General Provisions is regulated as follows Article 1 point 1 states: ${ }^{11}$

The Village is a village and a traditional village or what is referred to by another name, starting now referred to as Village, is a legal community unit that has the authority to manage and direct government affairs, the interests of the local community based on community initiatives, rights of origin, and/or rights traditionally recognized and respected in the system of government of the Unitary Republic of Indonesia.

The Village was formed with the aim of a professional, efficient and effective, open and responsible village government; improve services for villagers to accelerate the realization of public welfare; increase the socio-cultural resilience of rural communities in order to realize rural communities that can maintain social unity as part of national resilience; improve the economy of rural communities and overcome national development gaps, and strengthening village communities as the subject of development. ${ }^{12}$ In order to achieve the above objectives, it is necessary to build a sound financial management system.

Village financial management is the whole activity, which includes planning, implementation, administration, reporting, and accountability of village finances. ${ }^{13}$ Village financial management requires the existence and completeness of village officials. ${ }^{14}$ Village financial management based on governance principles, namely transparent, accountable and participatory and carried out to realize the Village as a government that is foremost and closest to the people, strong, advanced, independent, and democratic that can carry out governance and development towards a just, prosperous, and affluent society. ${ }^{15}$ This is a noble aim as glorious as APIP's role in maintaining it so that village financial management can be realized following its ideals. One oversight approach that APIP can take is to look at risks that can hinder village budget management goals. APIP must pay attention to how high the level of risk that has occurred. After that, it must be associated with existing internal controls to anticipate it. The

\footnotetext{
${ }^{9}$ Kirana Kawengian, Elfie Mingkid, "PERANAN KOMUNIKASI PEMERINTAH DALAM PELAKSANAAN PROGRAM BERSIH KAMPUNG (Studi Pada Pemerintah Desa Lopana Satu Kecamatan Amurang Timur)", $e$ journal “Acta Diurna” 6, no. 2 (2017): 1-15, 7.

${ }^{10}$ Riawan. Hukum Administrasi Negara, penerbit PT.Raja Grafindo Persada, Jakarta, 2009, Hlm: 197.

11 Afriniko, "POLITIK HUKUM OTONOMI DESA BERDASARKAN UNDANGUNDANG NOMOR 6 TAHUN 2014 TENTANG DESA”, JOM Fakultas Hukum 2, no. 2 (2015): 1-15, 11.

12 Nellis Mardhiah, "IDENTIFIKASI TUJUAN DAN SASARAN PEMBANGUNAN DESAKABUPATEN ACEH BARAT”, Jurnal Public Policy 3, no. 1 (2017): 177-188, 179, DOI: 10.35308/jpp.v3i1.753.

13 Endra Wijaya, Mochamad Firmansyah Roni, "PRAKTIK PENGELOLAAN KEUANGAN DESA DAN FAKTOR-FAKTOR YANG MEMENGARUHINYA (Practice of Village Fund Management and Its Affecting Factors)", Jurnal Ilmiah Kebijakan Hukum 13, no.2 (2019): 165-184, 167, DOI: 10.30641/kebijakan.2019.V13.165-184.

${ }^{14}$ Inten Meutia, Liliana, "PENGELOLAAN KEUANGAN DANA DESA", Jurnal Akuntansi Multiparadigma 8, no. 2 (2017): 336-352, 338, DOI: 10.18202/jamal.2017.08.7058.

15 Taufeni Taufik, "PENGELOLAAN KEUANGAN DESA DALAM SISTEM KEUANGAN NEGARA REPUBLIK INDONESIA”, Jurnal Ekonomi Universitas Riau 17, no. 1 (2009): 1-11, 2.
} 
higher the potential risk, the more detailed and numerous the work steps in APIP supervision. Let's examine the process of village financial management and experience over the past few years. We can identify several risks, both at the level of risk of the village government entity and its activities. These risks can be categorized as business risks motivated by fraud.

\section{Village Budget Allocation}

Based on the village provisions stipulated in Law No. 6 of 2014 above, during the JokowiJK administration in the 2014-2019 period, the development policy began in the villages. ${ }^{16}$ President Jokowi has proved this by increasing the number of village funds from year to year. Until the end of his term of office, in the first period of 2014 to 2019, the number of funds disbursed for each Village's construction reached 1 billion rupiahs with a total budget allocated for 2019 totaling 70 trillion rupiahs. ${ }^{17}$ Anwar Sanusi, Secretary-General of the Ministry of Villages of Disadvantaged Regions and Transmigration (in the future abbreviated as the Ministry of PDTT), stated that for 2019 the number of village funds received by each Village in Indonesia would reach 1 billion rupiahs. ${ }^{18}$ Nationally, during the five years of Jokowi's leadership as President of the Republic of Indonesia, the graph of the amount of the Village Budget for the 2015-2019 period distributed to the regions was as follows:

Graph: Village Fund Budget for the Period of 2015-2019

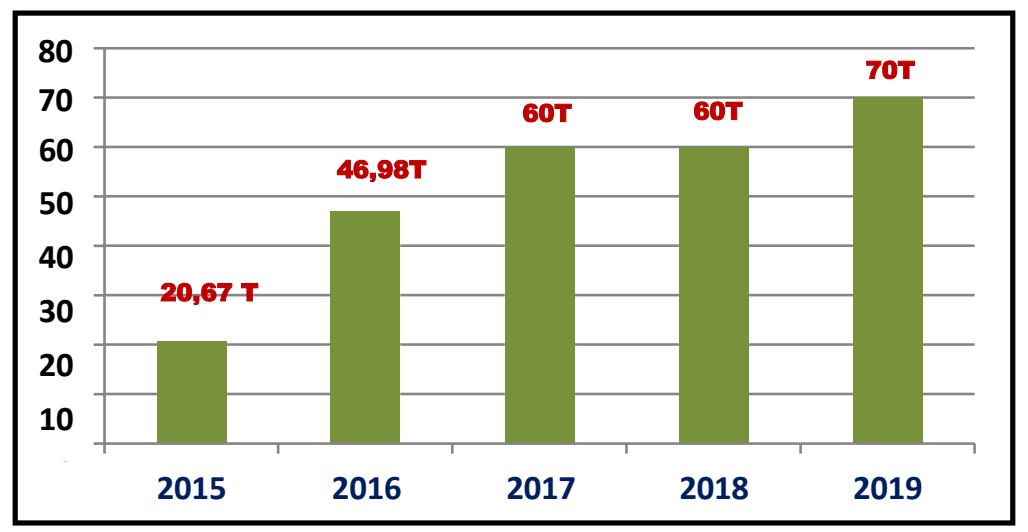

Data Source: Sandro Gatra, 26/2/2019, https://nasional.kompas.com ${ }^{19}$

The Secretary-General of the Ministry of Home Affairs, Hadi Prabowo, stated that the granting of village funds referred to Law number 6 of 2014 concerning Villages that were currently given a broader mandate and authority and implementation of development. This mandate and authority were given as one of President Jokowi's efforts to accelerate the development of the Village by continuing to improve and evaluate the implementation and implementation of the development, which the budget was given entirely to the village head. Minister of the Village for the Development of Disadvantaged Regions and Transmigration (Minister of DPDTT), Eko Putro Sandjojo, stated that the allocation of village funds for the

\footnotetext{
${ }^{16}$ Mochdar Soleman, Mohammad Noer, "NAWACITA SEBAGAI STRATEGI KHUSUS JOKOWI PERIODE OKTOBER 2014-20 OKTOBER 2015”, Jurnal Kajian Politik dan Masalah Pembangunan 13, no. 1 (2017): 1961$1975,1969$.

${ }^{17}$ Until the end of his term of office, in the first period of 2014 to 2019 , the number of funds disbursed for the construction of each Village reached 1 billion rupiahs with a total budget allocated for 2019 totaling 70 trillion rupiahs, ttps://tirto.id, accessed on February 27, 2020.

18 The village funds received by each Village in Indonesia in 2019 reach 1 billion rupiahs, https://nasional.kontan.co.id, accessed on February 27, 2020).

19 Grafik Jumlah Anggaran Desa Periode tahun 2015-2019 yang di distribusikan kedaerah-daerah, https://nasional.kompas.com, accessed on March 4, 2020.
} 
period 2019-2024 amounted to 400 trillion rupiahs. For 2020 the stipulated village budget is 72 trillion rupiahs. ${ }^{20}$ During the second administration, President Jokowi continued to increase village funds as proof that he really wanted to carry out development evenly and not just focus on cities. This is intended so that economical transportation from villages to cities and vice versa runs smoothly.

\section{Criminal Policy on Corruption Management of Village Heads}

The criminal policy theory proposed by Muladi and Arief states, "in the handling of criminal acts there are two (2) criminal policy theories that can be used in Law Enforcement, namely Penal Policy and Non-Penal Policy". ${ }^{21}$ The penal policy is the prevention of crimes committed through a judicial process, which ultimately constitutes a reward or punishment for the perpetrator. ${ }^{22}$ Simultaneously, the Non-Penal Policy is crime prevention that prioritizes the prevention of crimes committed through coaching aimed at preventing before the crime occurs and/or so that the offender does not repeat his actions. ${ }^{23}$

Prevent village heads from deviating from their positions, especially in managing village funds, are essential so that non-penal policy theories are elaborated to realize the same view between APIP and APH in handling community complaints regarding village fund irregularities committed by village heads in the South Lampung Regency. APIP's task in handling community complaints about irregularities in village funds should be more intense in conducting coaching and supervision related to village fund management starting from the stages of budget planning, implementation, and accountability. APIP and APH's synergy also needs to be strengthened as a Supporting Entity in internal government oversight.

Efforts to realize the synergy of APIP and APH have been realized by the existence of a cooperation agreement between the Ministry of Home Affairs representing the Government Internal Supervisory Apparatus (APIP) with Law Enforcement Officials (APH) consisting of the Attorney General's Office and the Republic of Indonesia's Police which was held on February 28, 2018. Even though the cooperation agreement has been held, but in fact, there are still some crucial issues that deserve to be studied internally, which is more substantive, including the attitudes of the attorney institution and the police when finding an abuse of authority by the village head. In practice in the field, they still retain their institutions' authority so that the cases found are not submitted to APIP as the leading sector in handling cases of abuse of authority of the village head.

To avoid differences of opinion in handling the abuse of authority by the village head, the effort must be made to increase coordination between APIP and APH. In handling cases in the field, criteria and follow-up are distinguished between administrative errors and criminal errors. Criteria for administrative errors are as follows:

a. There are no state / regional financial losses;

b. There are state / regional financial losses and have been processed through compensation claims or treasury demands no later than 60 days after the APIP, or BPKP inspection report is received by the official or has been followed up and declared to be completed by APIP or BPKP;

c. Is part of the discretion as long as the objectives and conditions for using the discretion are

\footnotetext{
${ }^{20}$ Eko Putro Sandjojo stated that the allocation of village funds for the period 2019-2024 amounted to 400 trillion rupiahs. For 2020 the stipulated village budget is 72 trillion rupiahs, https://nasional.kompas.com, 2/26/2019, accessed on March 4, 2020.

${ }^{21}$ Muladi dan Badra Nawawi Arif, Teori-teori dan Kebijakan Pidana (Bandung: Alumni, 1998), 21.

22 Vivi Ariyanti, "KEBIJAKAN PENEGAKAN HUKUMDALAM SISTEM PERADILAN PIDANA INDONESIA", Jurnal Yuridis 6, no. 2 (2019): 33-54, 37, DOI: 10.35586/jyur.v6i2.789.

23 Rina Melati Sitompul, "KEBIJAKAN NON PENAL DALAM UPAYA PENCEGAHAN DAN PERLINDUNGAN KORBAN TINDAK PIDANA PERDAGANGAN ORANG (TRAFIKING) (Studi Kasus Provinsi Sumatera Utara)", USU Law Journal 2, no. 3 (2014): 190-204, 194.
} 
met or;

d. It is the government's administration as long as it is following the general principles of good governance.

Both explicitly and implicitly, the Regional Government Law and the Government Administrative Law instructed APIP to oversee and investigate government organs' administrative errors. At the same time, the APH was tasked with investigating and following up on criminal errors. The problem that will be analyzed in this study is related to the causes and procedures for handling complaints from village heads suspected of deviating from the budget of Tanjungsari Village, South Lampung in 2016.

The method used in collecting data is a normative and empirical juridical approach. The data that has been collected is then analyzed using qualitative analysis methods. This means that the data described in this study uses information and explanations in the form of sentences that are easy to read and understand to be interpreted and then summarized in general to answer the problem under study.

\section{B. Discussion}

\section{Factors that Cause Corruption}

Based on the results of an interview with Robangi as the Head of Tanjung Sari Village, Natar Subdistrict, South Lampung Regency in his examination, he explained that during the management of the 2016 Village budget year, development activities were found in the form of physical activities and community empowerment whose implementation was not under the Budget Plan in the Revenue Budget and Tanjungsari Village Expenditures for the 2016 fiscal year. This was done solely to accommodate the community's wishes in fulfilling its vision and mission as village chief. Robangi does not intend to intentionally divert the budget of the village fund. Robangi is also willing to return the excess payment of village finances if the Inspectorate Team carries out an inspection process due to the administrative error. He hoped that APIP would be pleased to provide guidance and supervision in managing village funds starting from the planning, implementation, and accountability stages to minimize unconscious budgetary irregularities.

Related to the definition of corruption in the real sense from the perspective of Law No. 20 of 2001, Soepardi believes that there must be an element of state financial losses and/or the country's economy. Whereas what is meant by state financial losses are losses caused by acts against the law or acts of abuse of authority, opportunities, or means that exist in a person or legal entity due to his position, and this is done in connection with acts of enriching oneself or another person or a corporation. ${ }^{24}$

Alatas states that there are seven corruption typologies, namely; 1) Transactive corruption, corruption which shows a mutual agreement between the giving and receiving; parties for mutual benefit where both parties are equally active in carrying out acts of corruption 2) Extensive corruption, corruption include certain forms of corruption in which the giver is forced to bribe so as not to endanger himself, his interests, his people or other matters that he values; 3) Investive corruption, corruption involving an offer of goods or services without any direct linkage to certain benefits which obtained by the giver, in addition to the benefits that are expected to be obtained in the future; 4) Nepotistic corruption, corruption in the form of giving special treatment to friends or who have a close relationship in order to occupy public positions. In other words, prioritizing the closeness of relationships and contrary to applicable norms and rules; 5) Automatic corruption, corruption committed by individuals because they have the

\footnotetext{
${ }^{24}$ Deddy Mulyadi Soepardi, Post-Monetary Crisis State Financial Management in Indonesia (Jakarta: Rineka Cipta, 2012), 4.
} 
opportunity to benefit from their knowledge and understanding of something only known to themselves; 6) Supportive corruption, the corruption that triggers the creation of an atmosphere that is conducive to protect or maintain the existence of acts of corruption and 7) Defensive corruption, acts of corruption that are forced to do in order to defend themselves from extortion.

Andi Hamzah, in his dissertation, listed several causes of corruption, namely; 1) The lack of civil servants' salaries compared to the increasing needs; 2) Indonesian cultural background, which is the source or cause of widespread corruption; 3) Poor management and less effective and efficient control. ${ }^{25}$ This gives people opportunities for corruption. Based on the findings in the dissertation, if it is associated with a public complaint case over alleged budget irregularities in Tanjung Sari Village in 2016, then what Tanjung Sari (Robangi) Village Head did is not a corrupt behavior because based on the results of the APIP examination the deviation is an administrative error caused by the lack of understanding of the budget management provisions by the Village Head. Whereas Hadjon stated that, in general, the state administration law covers the fields of regulation, including:

a. Regulations regarding the enforcement of order and security, health, politeness by using rules of conduct for citizens which are upheld and further determined by the government;

b. Regulations aimed at providing social security for the people;

c. Regulations regarding spatial planning established by the government;

d. Regulations relating to maintenance tasks from the government, including assistance to private activities in the context of public services;

e. Regulations relating to tax collection;

f. Regulations concerning the protection of the rights $\&$ interests of citizens of the government;

g. Regulations relating to law enforcement in state administration;

h. Regulations regarding the supervision of higher government organs against lower organs;

i. Regulations regarding the position in the law of government employees.

Based on the description above, it can be concluded that the factor causing the Village Head to deviate the Village Fund is due to his ignorance in managing Village Funds that are not following administrative provisions. This is consistent with the theory put forward by Hadjon in point ' $\mathrm{g}$ ', which states "regulations relating to the enforcement of state administrative law". Then the administrative deviation committed by the village head is not a crime.

\section{APIP's authority in Handling Reports/Complaints}

\section{a. Formal Provisions}

Riski Maulana, as Lampung Regional Police Investigator, said that the legal procedures for the coordination of APIP and APH in handling reports or complaints from the public regarding regional government implementation refer to the cooperation agreement between the Ministry of Home Affairs represented by APIP and APH consisting of the Attorney General and the Indonesian Police. on February 28, 2018. According to Riski Maulana, Several crucial issues need to be studied substantively, namely the APIP budget issue in carrying out activities. Without the APIP and APH budget, it will be challenging to realize synergy in aspects of practice.

The signing of this cooperation agreement in terms of normative aspects is intended to build excellent and integrated coordination between APIP and APH to handle and eradicate criminal acts of village fund corruption. The aim is as an operational guideline for the Regional Government Inspectorate, the Financial and Development Supervisory Agency (BPKP), the Attorney General's Office, and the police in strengthening work synergy in handling public

\footnotetext{
${ }^{25}$ Andi Hamzah, Kitab Undang-Undang Hukum Pidana dan Kitab Undang-Undang Hukum Acara Pidana, (Jakarta: Rineka Cipta, 2015), 11.
} 
complaints that indicate corruption. This is useful for implementing an effective, efficient, and accountable government to realize regional autonomy. The scope of the cooperation agreement between APIP and APH is (a) the exchange of data and information, (b) the mechanism for handling and complaints, and (c) the increase of human resources capacity. The implementation of those three points of agreement are as follows:

1) APIP and APH agreed to exchange data and/or information on reports or complaints from the public, which indicated corruption. The data and/or information includes: (a) Community reports or complaints (b) Supporting evidence of community reports or complaints (c) Written notification of the results of the handling of reports or public complaints by APIP and APH or (d) Data and/or information as mentioned above except the reporter's identity.

2) Exchange of data and/or information as above is done at (a) the stage after the issuance of the report on the results of the examination by APIP to APH (b) the investigation stage by APH.

3) The parties are obliged to maintain the confidentiality of data and/or information received and cannot be given to other parties without the parties' agreement.

The cooperation agreement made between the Minister of Home Affairs, the Attorney General, and the Head of the Indonesian National Police is theoretically following Atmosudirjo's view that states that the principles of state administrative law consist of(a) The principle of the jurisdiction (rechtmatingheid), every action of a state administration official may not violate the law or must be under a sense of justice and propriety (b) The principle of legality (wetmatingheid), every action of a state administration official must have a legal basis (basic rules are underlying it). Moreover, Indonesia is a state of law. The principle of legality is the most crucial thing in every government action, and (c) The principle of discretion, the freedom of a state administration official to make decisions based on his own opinion but not in conflict with legality. ${ }^{26}$

In connection with Atmosudirjo's view above, APIP's steps as a supervisor and coach of the regional government apparatus are appropriate. However, in the implementation, it requires a budget from the state to support the tasks assigned to APIP and APH in realizing effective and efficient governance as intended from regional autonomy.

\section{b. Report Making/Complaints Procedure}

In receiving reports or public complaints, several procedures must be carried out by the Government Internal Supervisory Apparatus (APIP) and other APIP members, as follows:

1) The parties that receive reports/complaints from the public are indicated as a criminal act of corruption if they meet a report or complaint requirements. These requirements contain at least the following: (a) identity data of the name and address of the reporter or complainant accompanied by a photocopy of ID card or another identity (b) information regarding the alleged perpetrators of corruption is accompanied by preliminary evidence/support including but not limited to objects/goods and documents.

2) While the subjects reported or complained by the community, including active local government administrators, namely (a) regional heads and deputy regional heads, (b) leaders and members of the Regional People's Representative Council, (c) State Civil Apparatus of Regional Government (d) heads Village and (e) village officials.

3) Regarding the coordination between APIP and APH South Lampung in handling cases that were complained by the public for alleged budget irregularities in Tanjung Sari Village, Natar District, South Lampung Regency in 2016, coordination with police investigators with Letter Number B/765/V/2019/Reskrimsus dated May 3, 2019, was carried out. This

\footnotetext{
${ }^{26}$ S. Prajudi Atmosudirjo, Hukum Administrasi Negara (Jakarta: Ghalia Indonesia, 1981), 16.
} 
is related to the transfer of case handling to the South Lampung Regency APIP over alleged funds irregularities in Tanjungsari Village, Natar District, in the 2016 fiscal year. The delegation of cases by the National Police investigator is based on the provisions stipulated in the Cooperation Agreement between the Minister of Home Affairs, the Attorney General, and the National Police Chief.

Joko Sapta Prihandaya, Inspector of South Lampung Regency, stated that the role of APIP in handling reports/complaints received from the community about irregularities committed by regional government administrators was to carry out an investigative examination process on the reports/ complaints of the community to explore empirical facts with mechanism, ${ }^{27}$ as follows:

1) APIP follows up on reports or public complaints received directly through investigative examinations to determine reports or complaints about whether administrative or criminal errors are suspected.

2) APIP can carry out investigative investigations to find suspected corruption. APIP will submit the case to APH for further investigation.

3) APH, in this case, finds administrative errors in handling reports or public complaints, then APH will submit the case received to APIP.

4) The criteria for administrative errors referred to are (a) there are no state / regional financial losses (b) there are state / regional financial losses and have been processed through compensation claims or treasury claims no later than 60 days after the APIP or BPK inspection results are received by officials or have been followed up and declared finished by APIP or BPK (c) is part of the discretion, as long as the objectives and conditions for using the discretion are met or (d) is the administration of the government as long as following the general principles of good governance.

Based on the provisions stipulated in Article 385 of Act Number 23 of 2014 concerning Regional Government, the legal procedures for handling public complaints are explained as follows:

1) Communities who submit complaints about alleged irregularities committed by the Village Head or Village Apparatus to APIP and/or APH.

2) APIP must examine the alleged irregularities reported by the public.

3) APH examines public complaints referred to above after first coordinating with APIP or the government agency in charge of supervision.

4) If, based on the examination results referred to in point three (3) above, evidence of administrative irregularities is found, the process is further submitted to APIP.

5) If based on the examination results referred to in point three (3), there is evidence of a criminal deviation, further proceedings are submitted to the APH under the legislation's provisions.

\section{c. Report Handling/Complaints}

Regarding the handling of reports/complaints from the public over alleged budget irregularities in Tanjung Sari Village, Natar Subdistrict, South Lampung Regency in the 2016 fiscal year, APIP has conducted an examination as a follow-up on case submissions received from the Lampung Regional Police Special Criminal Directorate according to Letter Number B/ 765/V/2019/Reskrimsus dated May 3, 2019, concerning the transfer of case handling over alleged funds misuse of Tanjung Sari Village Natar District 2016 fiscal year.

Based on the South Lampung Regent's order number 700/2895/III.01/2019 dated August 21, 2019, the audit team from APIP South Lampung had conducted an inspection process intending to find out empirical facts of the alleged budgetary deviation of the Tanjung Sari

\footnotetext{
${ }^{27}$ Results of interviews conducted on February 15, 2020.
} 
village of Natar District South Lampung Regency for the 2016 fiscal year. The inspection results were reported in writing with letter Number 700/37/III.01/LHP-K/IV/2019 dated December 31, 2019. The conclusion was that there were administrative errors in the management of Tanjung Sari Village Budget, Natar Subdistrict fiscal year 2016, due to the Village Head and the village apparatus's lack of understanding regarding the applicable laws and regulations.

The investigation results are by an interview with Suang Ginting as Technical Controller of the South Lampung Regency Inspectorate. He stated that explicitly the Regional Government Law and the Government Administrative Law had constructed that APIP had the duty to supervise and investigate government organs' administrative errors. At the same time, the APH was tasked with investigating and following up on criminal errors. Coordination between APIP and APH is needed in the context of handling public complaints aimed at becoming operational guidelines in coordinating to support the synergy of cooperation between the parties in handling reports or public complaints about whether the organizer is indicated as a criminal offense or administrative violation in order to realize an effective, efficient and accountable local government. This is in order to realize the objectives of regional autonomy.

Tri Wahyudi, as the auditor of the South Lampung Regency Inspectorate, stated that the coordination and integrity of APIP and APH need to be continuously improved so that there is no ambiguity in the conduct of regional government in acting for fear of being caught up in a crime or looking for mistakes to be convicted. The essence of APIP and APH coordination is that public complaints can be selected to distinguish administrative and criminal violations. ${ }^{28}$ This is because not all violations committed by regional government administrators must be criminally resolved. Criminal treatment is a last resort (ultimum remedium). With the memorandum of understanding between APIP and APH, handling complaints and/or public reports is coordinated in advance to assess whether complaints from the community indicate criminal or administrative violations. If there is an administrative violation, the settlement must be submitted to APIP, but it is submitted to APH if a criminal act is committed.

\section{d. Results}

Based on the facts of the examination carried out on the village head of Tanjungsari, Natar Lampung Selatan District and the information obtained from the interviews with the informants mentioned above, the results of the research that have been carried out can be concluded as follows:

1) The deviation of the Tanjung Sari Village fund budget for the 2016 fiscal year allegedly by the Tanjungsari village head of Natar Subdistrict was caused by a lack of understanding of the applicable regulations. This resulted in errors in the administration of activities where the Tanjungsari village head carried out physical development work and community empowerment activities that were not included in the APBDes 2016 fiscal year's budget plan. The criterion for administrative error is an overpayment of village financial losses. It has been processed through compensation claims or treasury demands no later than 60 days after the APIP inspection report is received by the official or followed up declared to be completed by APIP.

2) Based on the investigations carried out, the APIP Auditor Team did not find any indication of a criminal act against Robangi as the village head who was reported by the community for allegedly committing a criminal act of corruption. However, the village head in carrying out activities was not supported by an excellent administrative system. The audit team had not found indications of state losses used by village heads.

3) The Coordination Procedure between APIP and APH for Handling Public Complaints

\footnotetext{
${ }^{28}$ Results of interviews conducted on February 15, 2020.
} 
related to alleged budget irregularities in Tanjungsari Village, Natar District, South Lampung Regency, has been carried out by the following provisions:

a) Communities that submit reports/complaints on alleged irregularities committed by the Village Head or Village Apparatus to APIP and/or APH.

b) APIP is obliged to conduct an examination of alleged irregularities complained of by the public.

c) APH examines reports/complaints submitted by the public referred to above after first coordinating with APIP or the non-ministerial government agency in charge of supervision.

d) If, based on the results of the inspection referred to in point three (3) above, evidence of administrative irregularities is found, further proceedings are submitted to APIP.

e) If based on the examination results as referred to in point three (3), evidence of criminal deviation is found, the process is further submitted to APH under statutory provisions. Coordination between APIP and APH in South Lampung Regency has run well so that the role of APIP as a supervisor and coach of the regional government apparatus to realize effective and efficient governance can be carried out following the objectives of regional autonomy.

4) APIP as the government's internal auditor, has a vital role in guarding village fund management accountability, both in assurance and consultancy. This is regulated in Article 11 PP No. 60/2008, which provides adequate confidence in the compliance, efficiency, and effectiveness in achieving the objectives of the implementation of the tasks and functions of government agencies in providing early warning and increasing the effectiveness of risk management in carrying out tasks, and maintaining and improving quality in governance implementation of duties.

\section{Conclusion}

The deviation of the Tanjung Sari Village fund budget for the 2016 fiscal year allegedly by the Tanjungsari village head of Natar District was due to a lack of understanding of the applicable regulations. This resulted in errors in the administration of activities where the Tanjungsari village head carried out physical construction work and community empowerment activities that were not in the Village Budget and Expenditure Budget (APBDes) for the 2016 fiscal year. Based on the investigation results, the APIP Auditor Team found no indication of a crime committed by Robangi as the village head reported by the public on suspicion of committing a criminal act of corruption. However, the village head in carrying out activities is not supported by an excellent administrative system. The audit team did not find any indication of the state losses used by the village head.

Coordination between APIP and APH in South Lampung Regency has run well so that the role of APIP as a supervisor and coach of the regional government apparatus to realize effective and efficient governance can be carried out following the objectives of regional autonomy. APIP's internal auditors are very instrumental in overseeing accountability in village fund management, both in terms of assurance and consultation. This is regulated in Article 11 of the Government Regulation No. 60 of 2008, which provides adequate confidence in the observance, efficiency, efficiency, and effectiveness of achieving the objectives of carrying out local government agencies' tasks and functions.

\section{A. Journal}

\section{REFERENCES}

Afriniko. "POLITIK HUKUM OTONOMI DESA BERDASARKAN UNDANGUNDANG NOMOR 6 TAHUN 2014 TENTANG DESA", JOM Fakultas Hukum 2, no. 2, 2015: 115.

Ariyanti, Vivi. "KEBIJAKAN PENEGAKAN HUKUMDALAM SISTEM PERADILAN 
PIDANA INDONESIA", Jurnal Yuridis 6, no. 2, 2019: 33-54, DOI: 10.35586/jyur.v6i2.789.

Bunga, Marten., Aswari, Aan., Djanggih, Hardianto. "KONSEPSI PENYELAMATAN DANA DESA DARI PERBUATAN KORUPSI". Halu Oleo Law Review 2, no. 2, 2018: 448-459, DOI: $10.33561 /$ holrev.v2i2.4318.

Hans, Shela Delvia., et.al, "PENGELOLAAN DANA DESA DI TINJAU DARI PERSPEKTIF PENCEGAHAN KORUPSI", Jurnal Akta Yudisia 5, no. 1, 2020: 1-26, 8, DOI: 10.35334/ay.v5i1.1215.

Herdiana, Dian. "KECENDERUNGAN PERILAKU KORUPTIF KEPALA DESA DALAM PEMBANGUNAN DESA". Matra Pembaruan 3, no. 1, 2019: 1-11, DOI: 10.21787/mp.3.1.2019.1-11.

Kawengian, Kirana., Mingkid, Elfie "PERANAN KOMUNIKASI PEMERINTAH DALAM PELAKSANAAN PROGRAM BERSIH KAMPUNG (Studi Pada Pemerintah Desa Lopana Satu Kecamatan Amurang Timur)", e-journal “Acta Diurna” 6, no. 2, 2017: 1-15.

Mardhiah, Nellis. "IDENTIFIKASI TUJUAN DAN SASARAN PEMBANGUNAN DESAKABUPATEN ACEH BARAT”, Jurnal Public Policy 3, no. 1, 2017: 177-188, DOI: 10.35308/jpp.v3i1.753.

Meutia, Inten., Liliana. "PENGELOLAAN KEUANGAN DANA DESA", Jurnal Akuntansi Multiparadigma 8, no. 2, 2017: 336-352, DOI: 10.18202/jamal.2017.08.7058.

Noviati, Cora Elly. "DEMOKRASI DAN SISTEM PEMERINTAHAN". Jurnal Konstitusi 10, no. 2, 2013: 333-354, DOI: 10.31078/jk\%25x.

Sagita, Novie Indrawati. "PARTISIPASI WARGA MASYARAKAT DALAM PENILAIANKINERJA KECAMATAN DI KOTA BANDUNG”, CosmoGov 2, no. 2 (2016): 308-329, DOI: 10.24198/cosmogov.v2i2.10009.

Sitompul, Rina Melati. "KEBIJAKAN NON PENAL DALAM UPAYA PENCEGAHAN DAN PERLINDUNGAN KORBAN TINDAK PIDANA PERDAGANGAN ORANG (TRAFIKING) (Studi Kasus Provinsi Sumatera Utara)". USU Law Journal 2, no. 3, 2014: 190-204.

Soleman, Mochdar., Noer, Mohammad. "NAWACITA SEBAGAI STRATEGI KHUSUS JOKOWI PERIODE OKTOBER 2014-20 OKTOBER 2015". Jurnal Kajian Politik dan Masalah Pembangunan 13, no. 1, 2017: 1961-1975.

Taufik, Taufeni. "PENGELOLAAN KEUANGAN DESA DALAM SISTEM KEUANGAN NEGARA REPUBLIK INDONESIA”. Jurnal Ekonomi Universitas Riau 17, no. 1, 2009: $1-11$.

Wijaya, Endra., Roni, Mochamad Firmansyah. "PRAKTIK PENGELOLAAN KEUANGAN DESA DAN FAKTOR-FAKTOR YANG MEMENGARUHINYA (Practice of Village Fund Management and Its Affecting Factors)", Jurnal Ilmiah Kebijakan Hukum 13, no.2, 2019: 165-184, DOI: 10.30641/kebijakan.2019.V13.165-184.

Yani, Ahmad. "SISTEM PEMERINTAHAN INDONESIA: PENDEKATAN TEORI DAN PRAKTEK KONSTITUSI UNDANG-UNDANG DASAR 1945 (Indonesian Government System: Theory and Practice Approaches of 1945 'Constitution)". Jurnal Kebijakan Hukum 12, no. 2, 2018: 119-135, DOI: 10.30641/kebijakan.2018.V12.119-135.

\section{B. Books}

Abdullah, Rojali. Pelaksanaan Otonomi luas dengan Pemilihan Kepala Daerah secara Langsung. Jakarta: Raja Grafindo Persada, 2005.

Atmosudirjo, S.Prajudi. Hukum Administrasi Negara. Jakarta: Ghalia Indonesia, 1981.

Hadjon, Philipus M. Pengantar Hukum Administrasi Indonesia. Yogyakarta: Gajah Mada University Press, 1993.

Hamzah, Andi. Kitab Undang-Undang Hukum Pidana dan Kitab Undang-Undang Hukum 
Acara Pidana. Jakarta: Rineka Cipta, 2015.

Muladi., Arif, Badra Nawawi. Teori-Teori dan Kebijakan Pidana. Bandung: Alumni, 1998.

Riawan. Hukum Pemerintahan Daerah. Bandung: Citra Aditya Bakti, 2009.

Soepardi, Eddy Mulyadi. Pengelolaan Keuangan Negara Pasca Krisis Moneter di Indonesia, Jakarta: Rineka Cipta, 2012.

\section{Internet}

https://tirto.id, accessed on February 27, 2020.

https://nasional.kompas.com, accessed March 4, 2020.

https://nasional.kompas.com, accessed March 4, 2020.

www.bpp.go.id, accessed March 6, 2020.

https://nasional. kompas. com,_accessed March 6, 2020.

\section{Regulations}

Government Regulation Number 60 of 2008, concerning Government Internal Control System. Law Number 15 of 2004, concerning the Audit of State Finance Management and Responsibilities.

Law Number 30 of 2014, concerning Regional Government Administration.

Law Number 9 of 2015 jo. Law Number 23 of 2014 concerning Regional Government.

Regulation of the Minister of Home Affairs Number 113 of 2014 concerning Village Financial Management. 
